\title{
Experimental determination of the temperature dependence of oxygen-isotope fractionation between water and chitinous head capsules of chironomid larvae
}

\author{
Alex Lombino $\cdot$ Tim Atkinson • Stephen J. Brooks • Darren R. Gröcke • \\ Jonathan Holmes $\mathbb{D} \cdot$ V Vivienne J. Jones $\cdot$ Jim D. Marshall
}

Received: 15 June 2020 / Accepted: 26 March 2021 / Published online: 15 April 2021

(C) The Author(s) 2021

\begin{abstract}
Oxygen-isotope values of invertebrate cuticle preserved in lake sediments have been used in palaeoenvironmental reconstructions, generally with the assumption that fractionation of oxygen isotopes between cuticle and water $\left(\alpha_{\text {cuticle- } \mathrm{H}_{2} \mathrm{O}}\right)$ is independent of temperature. We cultured chironomid larvae in the laboratory with labelled oxygen-isotope water and across a range of closely controlled temperatures from 5 to $25{ }^{\circ} \mathrm{C}$ in order to test the hypothesis that fractionation of oxygen isotopes between chironomid head capsules and water $\left(\alpha_{\text {chironomid- } \mathrm{H}_{2} \mathrm{O}}\right)$ is independent of temperature. Results indicate that the hypothesis can be rejected, and that $\alpha_{\text {chironomid- } \mathrm{H}_{2} \mathrm{O}}$ decreases with increasing temperature. The scatter in the data suggests that further experiments are needed to
\end{abstract}

Co-authors are listed alphabetically.

\section{A. Lombino}

Environmental Change Research Centre, Department

of Geography, University College London,

London WC1E 6BT, UK

e-mail: alex.lombino@thermofisher.com

T. Atkinson

Environmental Change Research Centre, Department of Geography and Department of Earth Sciences, University College London, London WC1E 6BT, UK e-mail: t.atkinson@ucl.ac.uk

\section{S. J. Brooks}

Department of Life Sciences, Natural History Museum, Cromwell Road, London SW7 5BD, UK

e-mail: s.brooks@nhm.ac.uk verify the relationship. However, these results indicate that temperature-dependence of $\alpha_{\text {chironomid- }} \mathrm{H}_{2} \mathrm{O}$ should be considered when chironomid $\delta^{18} \mathrm{O}$ is used as a paleoenvironmental proxy, especially in cases where data from chironomids are combined with oxygen-isotope values from other materials for which fractionation is temperature dependent, such as calcite, in order to derive reconstructions of past water temperature.

Keywords Oxygen isotopes · Chironomids · Temperature-dependent isotope fractionation . Palaeoenvironments · Limnology

\footnotetext{
D. R. Gröcke

Department of Earth Sciences, Durham University, South Road, Durham DH1 3LE, UK

e-mail: d.r.grocke@durham.ac.uk

J. Holmes $(\square) \cdot$ V. J. Jones

Environmental Change Research Centre, Department

of Geography, University College London,

London WC1E 6BT, UK

e-mail: j.holmes@ucl.ac.uk

V. J. Jones

e-mail: vivienne.jones@ucl.ac.uk

J. D. Marshall

Department of Earth, Ocean and Ecological Sciences,

University of Liverpool, Liverpool L69 3GP, UK

e-mail: isotopes@liverpool.ac.uk
} 


\section{Introduction}

Oxygen-isotope records from lake sediments are valuable sources of palaeoclimatic information. Although authigenic carbonate is the material most commonly analysed, other minerals and biomolecules have also been used in lakes that do not precipitate carbonate or as complementary sources of data in those that do (Leng and Marshall 2004). The remains of aquatic invertebrates provide a promising source of material for oxygen-isotope analyses (Schimmelmann and DeNiro, 1986; Schimmelmann et al. 1986) and determinations have been undertaken on beetle exoskeletons (van Hardenbroek et al. 2012), cladoceran remains (Verbruggen et al. 2011; Schilder et al. 2015) and the larval head capsules of chironomids (Wooller et al. 2004; Verbruggen et al. 2010a,b). Several studies using specimens collected in the field have demonstrated a strong positive correlation between the oxygen-isotope ratio of host water $\left(\delta^{18} \mathrm{O}_{\mathrm{H}_{2} \mathrm{O}}\right)$ and invertebrate cuticle $\left(\delta^{18} \mathrm{O}_{\text {cuticle }}\right)$ (van Hardenbroek et al. 2012; Mayr et al. 2015; Verbruggen et al. 2011; Chang et al. 2018; Lasher et al. 2017). These investigations covered a wide range of geographical areas and a correspondingly wide range of $\delta^{18} \mathrm{O}_{\mathrm{H}_{2} \mathrm{O}}$ in the water bodies concerned, and the results have shown that the oxygen-isotope ratio of the host water appears to be the dominant control on $\delta^{18} \mathrm{O}_{\text {cuticle. }}$ This was previously noted by Wooller et al. (2004), who found a linear relationship between $\delta^{18} \mathrm{O}$ measured in chitinous head capsule and estimated annual average $\delta^{18} \mathrm{O}_{\mathrm{H}_{2} \mathrm{O}}$ of precipitation for four sites in eastern USA, Greenland and Baffin Island. By assuming that fractionation between chironomid head capsules and water was independent of temperature, they derived an initial estimate of the "biological fractionation factor" between chironomid and water of $\alpha_{\text {chironomid }-\mathrm{H}_{2} \mathrm{O}}$ $\approx 1.028$. (For a given substance, in this case chironomid head capsules, the fractionation factor $\alpha_{\text {chironomid- } \mathrm{H}_{2} \mathrm{O}}$ is defined as the ratio between ${ }^{18} \mathrm{O} /{ }^{16} \mathrm{O}$ in chironomid head capsules and water respectively, but can be accurately approximated from $\delta^{18} \mathrm{O}$ values as $\left.\left(1000+\delta^{18} \mathrm{O}_{\text {chironomid }}\right) /\left(1000+\delta^{18} \mathrm{O}_{\mathrm{H}_{2} \mathrm{O}}\right)\right)$. As chitin is the dominant constituent in the cuticle of chironomid head capsules, the assumption made by Wooller et al. (2004) has been extrapolated in the literature to imply that fractionation between chitin and water is independent of temperature. However, neither the original assumption nor the extrapolation has been tested experimentally. The strong relationship between $\delta^{18} \mathrm{O}_{\text {chironomid }}$ and $\delta^{18} \mathrm{O}_{\mathrm{H}_{2} \mathrm{O}}$ was confirmed experimentally by Wang et al. (2009), who cultured chironomid larvae in waters with near-constant $\delta^{18} \mathrm{O}_{\mathrm{H}_{2} \mathrm{O}}$ close to $-15.1 \%$ and $+6.5 \%$ in triple-replicated treatments at a constant temperature of $23{ }^{\circ} \mathrm{C}$. By also controlling the $\delta^{18} \mathrm{O}$ of the food provided to the cultured larvae, Wang et al. demonstrated that $69 \%$ of the oxygen atoms in the larvae were derived from the host water, and $31 \%$ from food. Subsequent studies have suggested that a proportion of chitin oxygen may also be derived from isotopically invariant atmospheric oxygen (Nielson and Bowen, 2010; Soto et al. 2013), although this source has not been included in estimates of fractionation in our study.

If $\alpha_{\text {chironomid- } \mathrm{H}_{2} \mathrm{O}}$ is indeed independent of temperature, it should be possible to reconstruct past values of $\delta^{18} \mathrm{O}_{\mathrm{H}_{2} \mathrm{O}}$ directly from measurements of $\delta^{18} \mathrm{O}_{\text {chironomid }}$ in fossil material, with obvious applications in palaeoclimate reconstruction. Wooller et al. (2004) noted similarities between chitin and aquatic cellulose in respect of oxygen-isotope fractionation from host water. Both have broadly similar fractionation factors (previous studies quote $\alpha$ values between about 1.023 and 1.028), suggesting similarity in the biochemical reactions by which oxygen derived from water is incorporated in the two polymers, despite the fact that cellulose is produced by plants and chitin by animals and fungi. Moreover, $\alpha_{\text {cellulose- } \mathrm{H}_{2} \mathrm{O}}$ is also generally regarded as temperature independent (Beuning et al. 1997). However, independence from temperature remains unproven for either biopolymer and results from culture experiments and field collections suggest there may in fact be temperature dependence of $\delta^{18} \mathrm{O}$ for Cladocera (Verbruggen et al. 2011; Schilder et al. 2015), and cellulose (Aucour et al. 1993). Clearly, temperature dependence needs either to be disproven or, if shown to be true, to be quantified in order for accurate reconstructions of $\delta^{18} \mathrm{O}_{\mathrm{H}_{2} \mathrm{O}}$ to be made.

Here, we report the results of a laboratory culture study of the influence of temperature on oxygen-isotope fractionation between host water and the chitinous head capsules of chironomid larvae using culture experiments under conditions of constant $\delta^{18} \mathrm{O}_{\mathrm{H}_{2} \mathrm{O}}$ and shared diet, leaving temperature as the variable to be investigated for its influence on $\delta^{18} \mathrm{O}_{\text {chironomid. }}$ 


\section{Materials and methods}

We reared larvae of the chironomid Chironomus riparius (Meigen 1804) from eggs (supplied by Huntington Life Sciences Ltd). This species was chosen based on its eggs being readily available. Eggs were reared in glass Erlenmeyer flasks, containing $2 \mathrm{~L}$ of bottled mineral water and $500 \mathrm{~g}$ of sand that was first combusted at $550{ }^{\circ} \mathrm{C}$ for six hrs to eliminate any organic matter that might have provided extraneous food sources. The flasks were placed inside isothermal cabinets set at nominal temperatures of 5, 10, 15, 20 and $25^{\circ} \mathrm{C}$. Duplicate experiments at each temperature (triplicate at $15^{\circ} \mathrm{C}$ ) were conducted concurrently in the same cabinet to minimize temperature differences between the replicates. The flasks were kept in complete darkness to inhibit photosynthetic activity and loosely sealed with aluminium foil to minimize evaporation. Typically, every other day, each flask was provided with $1.5 \mathrm{~mL}$ of a suspension of finely ground Tetramin fish food flakes. This was prepared weekly by blending $4 \mathrm{~g}$ of fish food flakes with $1 \mathrm{~L}$ of water and kept refrigerated. The isotopic composition of food was not measured but was assumed to be constant. Rationing was adjusted according to water quality and larval behaviour, because decomposition of uneaten food can lead to increased microbial activity and reduced dissolved oxygen concentration, which may subsequently hinder larval development. Water quality was maintained through regular partial water replacements by siphoning off one litre of water from each flask weekly and replacing it with stock mineral water stored at the relevant temperature. This ensured satisfactory dissolved oxygen concentration and optimal environmental conditions for growth and development. Experiment duration varied depending on larval growth rates but in all cases, experiments were terminated once the majority of larvae had reached their final instar.

Water samples were taken regularly throughout the experiments to track changes in $\delta^{18} \mathrm{O}_{\mathrm{H}_{2} \mathrm{O}}$ and water chemistry. Stable isotope analyses were undertaken using a Picarro WS-CRDS system at the University of Liverpool. Results were normalized onto the VSMOW scale using internationally distributed standards with an internal precision $< \pm 0.08 \%$.
Electrical conductivity, dissolved oxygen concentration and $\mathrm{pH}$ were measured at approximately weekly intervals using Camlab Handylab 1 battery-powered hand-held meter attached to a data logger. Water temperature was measured hourly using Tinytalk (TK0040) data loggers. At the end of each experiment, the contents of each flask were washed through a $1 \mathrm{~mm}$ mesh sieve and chironomid larvae picked from the retained residue using fine-tipped forceps before being frozen whole for storage. Only final instars were selected for isotope analyses. Following defrosting, head capsules were manually separated from larval bodies under a stereomicroscope $(\times 25$ magnification) using a mounted needle and fine-tipped forceps, taking care to remove as much of the digestive tract and muscle tissue as possible. The remaining outer portions of the head capsules were then subjected to chemical pre-treatment in three sequential steps: (1) 2:1 dichloromethane:methanol; (2) $0.25 \mathrm{M} \mathrm{HCl}$ and (3) $0.25 \mathrm{M} \mathrm{NaOH}$, each for $24 \mathrm{~h}$ at $20{ }^{\circ} \mathrm{C}$. This protocol had previously been found by experiment to maximize the elimination of non-chitinous material while minimizing the variability among replicated measurements of $\delta^{18} \mathrm{O}_{\text {chironomid }}$ (Lombino 2015). Nevertheless, it is possible that some non-chitinous material survived the pre-treatment, as proteins and lipids are both present alongside chitin in the make-up of the head capsules (Verbruggen et al. 2010a). Recognizing this possibility, we use the notation $\delta^{18} \mathrm{O}_{\text {chironomid }}$ rather than $\delta^{18} \mathrm{O}_{\text {chitin }}$ in describing our results. $\mathrm{A}$ minimum weight of $60 \pm 10 \mu \mathrm{g}$ was used for isotope analyses, equivalent to between 10 and 50 head capsules. The chironomid oxygen-isotope analyses were performed at the Stable Isotope Biogeochemistry Laboratory (SIBL, Durham University) using a TC/ EA coupled to a Delta V Advantage IRMS, via a ConFlo III. Since chironomid material is rich in nitrogen compounds, the isotopic analysis should take into account the interference of $\mathrm{N}_{2}$ gas generated from thermal combustion (Qi et al. 2011). The TCEA reactor was operated at $1400{ }^{\circ} \mathrm{C}$ with a $2 \mathrm{~m} \mathrm{GC}$ column at a temperature of $60{ }^{\circ} \mathrm{C}$ in order to avoid nitrogen interference. All ion traces show that there was no interference between the nitrogen peak and carbon monoxide peak of the chironomid material. Analytical uncertainties were $\leq \pm 0.64 \%$ (1SD) based on repeat analyses of three international reference standards (IAEA-600, IAEA-601, IAEA-602). 


\section{Results}

Conditions during the experiments are assumed to have remained within the ecological tolerances of the $C$. riparius larvae since no significant mortality events occurred during the experiments, although eggs failed to hatch in one of the $25^{\circ} \mathrm{C}$ cultures and only one analysis was available for $5{ }^{\circ} \mathrm{C}$. In the failed culture, some eggs had already hatched and died by start of the experiment. Anoxic conditions in the small vials used for transportation, which would have been exacerbated at $25{ }^{\circ} \mathrm{C}$, may have compromised the other eggs. The temperature, isotopic composition, $\mathrm{pH}$ and electrical conductivity showed little variation in each flask (Table 1): fluctuations in dissolved oxygen concentration were probably associated with changes in the rate of respiration by the chironomid larvae and the decomposition of uneaten food. Temperature had a strong influence on the rate of larval development, which is consistent with previous findings (Hauer and Benke 1991). In our study, there was a decrease in development rate of $\sim 4$ days ${ }^{\circ} \mathrm{C}^{-1}$ between 5 and $25^{\circ} \mathrm{C}$.

The oxygen-isotope composition of the pretreated head capsules varied between $+13.8 \%$ and +16.3 $\% o$ across the range of temperatures. This variability is around twice the reported analytical precision of $\leq \pm 0.64 \%$. On average, $\delta^{18} \mathrm{O}_{\text {chironomid }}$ values were $\sim 1.3 \%$ o lower in larvae reared at $25{ }^{\circ} \mathrm{C}$ than in larvae reared at $5{ }^{\circ} \mathrm{C}$, with $\alpha_{\text {chironomid- } \mathrm{H}_{2} \mathrm{O}}$ varying between 1.021 and 1.024 across the tested temperature range. There is a positive correlation between
$1000 \ln \alpha{ }^{18} \mathrm{O}_{\text {chironomid- } \mathrm{H}_{2} \mathrm{O}}$ and temperature (Fig. 1, $\left.\mathrm{r}^{2}=0.53 ; p<0.05 ; n=9\right)$.

The best-fit relationship between $\alpha^{18} \mathrm{O}_{\text {chironomid- } \mathrm{H}_{2} \mathrm{O}}$ and temperature is:

$1000 \ln \alpha^{18} O_{\text {chironomid- } \mathrm{H}_{2} \mathrm{O}}=8.45 \times\left(1000 \times T^{-1}\right)-6.52$

where $\mathrm{T}$ is temperature in Kelvin. The standard error of estimate for $1000 \ln \alpha^{18} \mathrm{O}_{\text {chironomid- } \mathrm{H}_{2} \mathrm{O}}$ is 0.6 , which is comparable to the analytical uncertainty in meas-

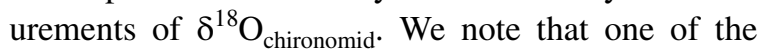

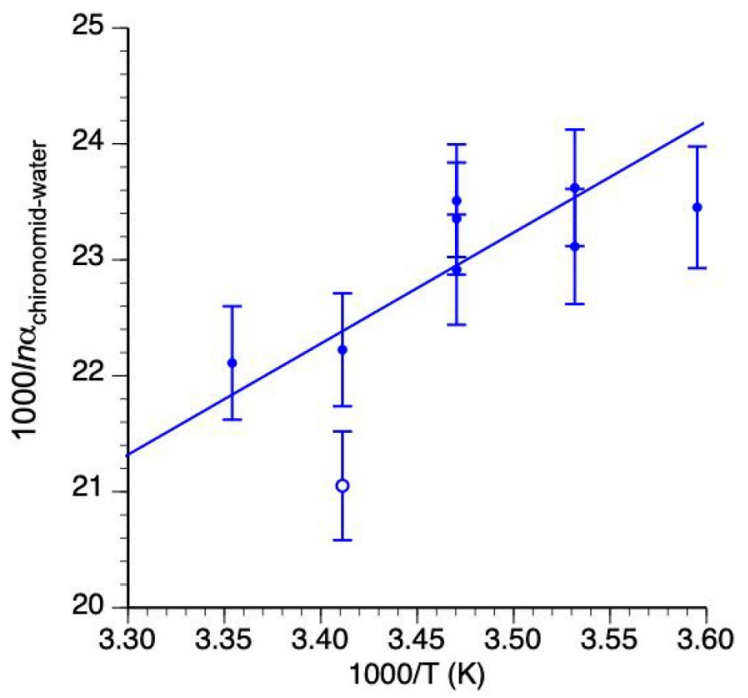

Fig. $11000 \ln \alpha^{18} \mathrm{O}_{\text {chironomid- } \mathrm{H}_{2} \mathrm{O}}$ as a function of inverse temperature. Error bars represent $1 \mathrm{SD}$ analytical uncertainty. Open symbol denotes an outlier that was excluded from Eq. 2

Table 1 Water temperature and water composition of each culture experiment, along with the measured $\delta^{18} \mathrm{O}_{\text {chironomid }}$ values and chironomid-water fractionation factors ( $\alpha$-values)

\begin{tabular}{llllllll}
\hline Temperature & $\delta^{18} \mathrm{O}_{\mathrm{H}_{2} \mathrm{O}}$ & $\mathrm{pH}$ & Dissolved oxygen & $\begin{array}{l}\text { Electrical } \\
\text { conductivity }\end{array}$ & $\begin{array}{l}\text { Larval } \\
\text { develop- } \\
\text { ment } \\
(\text { days })\end{array}$ & $\delta^{18} \mathrm{O}_{\text {chironomid }}$ & $\alpha_{\text {chironomid- } \mathrm{H}_{2} \mathrm{O}}$ \\
& & & & & & \\
$\left({ }^{\circ} \mathrm{C}\right)$ & $(\%$ VSMOW $)$ & & $\left(\mathrm{mg} \mathrm{L}^{-1}\right)$ & $\left.\mathrm{Scm}^{-1}\right)$ & VSMW $)$ & \\
\hline $5.6 \pm 0.4$ & $-7.4 \pm 0.18$ & $7.2 \pm 0.2$ & $7.3 \pm 1.5$ & $230 \pm 12$ & 130 & 16.8 & 1.024 \\
$10.5 \pm 0.4$ & $-7.6 \pm 0.18$ & $7.4 \pm 0.2$ & $7.1 \pm 1.3$ & $256 \pm 18$ & 110 & 16.1 & 1.024 \\
$10.5 \pm 0.4$ & $-7.5 \pm 0.21$ & $7.2 \pm 0.2$ & $7.2 \pm 1.4$ & $259 \pm 25$ & & 15.6 & 1.023 \\
$15.2 \pm 0.4$ & $-7.5 \pm 0.15$ & $7.3 \pm 0.1$ & $6.4 \pm 1.9$ & $259 \pm 16$ & 90 & 15.9 & 1.024 \\
$15.2 \pm 0.4$ & $-7.3 \pm 0.07$ & $7.4 \pm 0.2$ & $6.7 \pm 1.9$ & $247 \pm 18$ & & 16.3 & 1.023 \\
$15.2 \pm 0.4$ & $-7.4 \pm 0.11$ & $7.3 \pm 0.2$ & $6.2 \pm 2.3$ & $259 \pm 14$ & & 15.7 & 1.023 \\
$20.2 \pm 0.3$ & $-7.3 \pm 0.16$ & $7.6 \pm 0.1$ & $6.8 \pm 1.0$ & $250 \pm 7$ & 70 & 15.0 & 1.022 \\
$20.2 \pm 0.3$ & $-7.3 \pm 0.14$ & $7.6 \pm 0.0$ & $6.8 \pm 1.1$ & $252 \pm 8$ & & 13.8 & 1.021 \\
$24.9 \pm 0.5$ & $-7.3 \pm 0.25$ & $7.5 \pm 0.2$ & $6.1 \pm 1.8$ & $292 \pm 17$ & 50 & 14.9 & 1.022 \\
\hline
\end{tabular}


results at $20{ }^{\circ} \mathrm{C}$ appears to be an outlier. The reason for this is unknown but could be related to additional dietary contributions from microorganisms originating from the decomposition of excess food. Omission of this apparent outlier alters the gradient and intercept of the linear regression so that:

$1000 \ln \alpha^{18} O_{\text {chironomid }-H_{2} O}=6.29 \times\left(1000 \times T^{-1}\right)+1.16$

with a stronger positive correlation between $1000 \ln \alpha^{18} \mathrm{O}_{\text {chironomid- } \mathrm{H}_{2} \mathrm{O}}$ and temperature $\left(\mathrm{r}^{2}=0.66\right.$; $p<0.05 ; n=8)$. The standard error of estimate for $1000 \ln \alpha^{18} \mathrm{O}_{\text {chironomid- } \mathrm{H}_{2} \mathrm{O}}$ is reduced to 0.4 .

\section{Discussion}

The systematic variability of $\alpha_{\text {chironomid- } \mathrm{H}_{2} \mathrm{O}}$ implies that temperature plays a small but potentially important role in controlling $\delta^{18} \mathrm{O}_{\text {chironomid }}$ values. For water of a given isotopic composition, the rate of variation of $\delta^{18} \mathrm{O}_{\text {chironomid }}$ with temperature is approximately- $0.1 \% \circ{ }^{\circ} \mathrm{C}^{-1}$ for the relationships expressed in both Eqs. 1 and 2 above (although slightly higher for Eq. 1 than for Eq. 2: -0.11 and $-0.09 \%{ }^{\circ} \mathrm{C}^{-1}$, respectively), i.e. lower than for other minerals often used in palaeo-lacustrine settings, such as calcite $\left(-0.24 \%{ }^{\circ} \mathrm{C}^{-1}\right.$; Kim and O'Neil 1997) and biogenic silica $\left(-0.2\right.$ to $-0.5 \%{ }^{\circ} \mathrm{C}^{-1}$; Brandriss et al. 1998 ; Juillet-Leclerc \& Labeyrie 1987; Leng \& Barker 2006). The cause of the variability in $\alpha_{\text {chironomid }-\mathrm{H}_{2} \mathrm{O}}$ with temperature is unknown, although it may be related to the faster larval development at higher temperature.

Results from this investigation are compared with culture experiments of Wang et al. (2009) and Soto et al. (2013) (Fig. 2a). Both studies involved culturing chironomids under controlled water isotopic composition and temperature $\left(23{ }^{\circ} \mathrm{C}\right.$ and $24{ }^{\circ} \mathrm{C}$ respectively), but the species they used differed from our study ( $C$. dilutus and $C$. tentans respectively; C.riparius in our work). The two data points from Wang et al. (2009) fit well with the results from chironomids extracted from surface sediments, for which van Hardenbroek et al. (2018) report the relationship $\delta^{18} \mathrm{O}_{\text {chironomid }}=0.89 \times$ $\delta^{18} \mathrm{O}_{\text {lake water }}+22.5$ (their Fig. 5). Figure 2a shows that the data from our study form a trend across the line joining the two data points from Wang
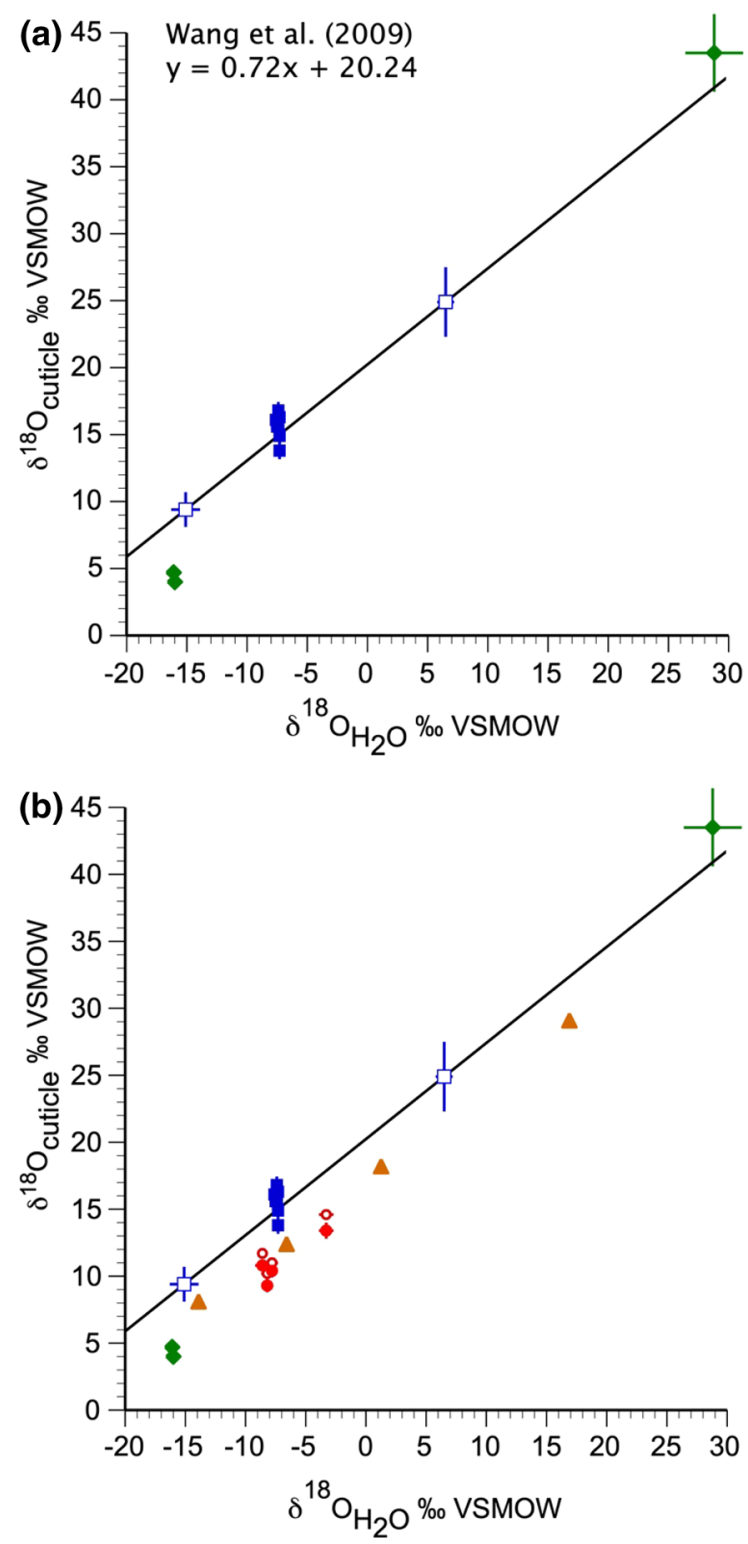

Fig. 2 a $\delta^{18} \mathrm{O}_{\text {chironomid }}$ versus $\delta^{18} \mathrm{O}_{\mathrm{H}_{2} \mathrm{O}}$ from Wang et al. (2009) (Chironomus dilutus: open blue squares-whole larvae, reared at $23{ }^{\circ} \mathrm{C}$ : uncertainties are $\pm 1 \mathrm{SD}$ of the replicate experiments), this study (Chironomus riparius: filled blue squares-head capsules) and Soto et al. (2013) (Chironomus tentans: green diamonds-larvae protein, reared at $24 \pm 0.5{ }^{\circ} \mathrm{C}$ ) For the present study each individual $\delta^{18} \mathrm{O}_{\text {chironomid }}$ value is plotted (Table 1) along with analytical uncertainty $( \pm 1 \mathrm{SD})$, although error bars for the $\delta^{18} \mathrm{O}_{\mathrm{H}_{2} \mathrm{O}}$ are too narrow to be visible. b Data in (a) are plotted with additional data for cladocerans (open red circles, whole Daphnia, filled red circles, ephippia, reared at 12 and $20{ }^{\circ} \mathrm{C}$ each water composition.) from Schilder et al. (2015) and brine shrimp chitin (brown triangles, from Nielson and Bowen 2010 , reared at room temperature. Only those values for cultures reared with $\delta^{18} \mathrm{O}_{\text {food }}$ of $14 \%$ are plotted here) are shown 
et al. (2009), with the data from rearing experiments at $>20{ }^{\circ} \mathrm{C}$ plotting on or below that line and those from $<20{ }^{\circ} \mathrm{C}$ plotting above. The trend of our data indicates the degree of scatter to be expected from variations in temperature over a $20{ }^{\circ} \mathrm{C}$ temperature range. On the other hand, the two groups of data from the study by Soto et al. (2013) lie respectively below and above the line. Although the measurement uncertainties for their data from the upper right in Fig. 2a are large enough to overlap the extrapolated Wang et al. (2009) line, this is not the case for their two data points at bottom left (Fig. 2a), whose deviations from the line far exceed the effect of the $1{ }^{\circ} \mathrm{C}$ difference in temperature that our experiments would predict. We do not have any explanation for this discrepancy other than the possibility that $C$. riparius (our study) and $C$. dilutus (Wang et al., 2009) share a common uptake of $72 \%$ of oxygen in chitin and associated tissue from environmental water, whereas Soto et al. (2013) estimate that $C$. tentans derives $87 \%$ from this source. We note that there are differences between the three studies in the preparation of chitinous material and in the techniques used to measure $\delta^{18} \mathrm{O}_{\text {chironomid, }}$, but these do not explain the differences in results. Our preparation and chitin purification steps removed both lipids and a substantial fraction of proteins from the larval head capsules, whereas Wang et al. (2009) analysed whole larvae without any chemical treatment and Soto et al. (2013) only extracted lipids from their samples. The results show agreement between the most and least treated larvae (our study and Wang et al., 2009) with deviation only for the intermediate treatment. All three studies used a high-temperature pyrolysis device to convert oxygen in chitin to $\mathrm{CO}$ gas for isotope ratio measurement. With respect to nitrogen interference from proteinaceous material, Soto et al. (2013) diverted the nitrogen produced by pyrolysis away from the source of the mass spectrometer, whereas this was not done by Wang et al. (2009) and this study. Qi et al. (2011) show that for $\delta^{18} \mathrm{O}$ measurements on keratin the results from the nitrogen diversion technique are on average about $3 \%$ above those on the same material without nitrogen diversion. Although a 3\%o downwards adjustment of the Soto et al. (2013) data would bring the data point at upper right in Fig. 2a into better alignment with the trend of the other studies, their point at lower left would be shifted even further away from the same trend. Further analytical research is required to ascertain the effects of nitrogen from proteinaceous material on TCEA oxygen isotope analysis.

Some support for the hypothesis of inter-specific differences as an explanation for the discrepancies between the three chironomid-based studies can be drawn from Fig. 2b, which includes additional data on chitinous material from the cladoceran Daphnia (Schilder et al. 2015) and the brine shrimp Artemia franciscana (Nielson and Bowen 2010). In neither study was nitrogen diversion technique employed or nitrogen interference investigated. The brine shrimp were cultured at room temperature which, was presumably constant (Nielson and Bowen, 2010), whereas the four treatments employed by Schilder et al. (2015) included a variation in temperature between 12 and $20{ }^{\circ} \mathrm{C}$. The brine shrimp data define a trend that is approximately parallel to the chironomid line and the cladoceran data from Schilder et al. (2015) lie on this trend. The degree of scatter in the cladoceran data is consistent with their $8{ }^{\circ} \mathrm{C}$ temperature range. However, both data sets plot on a line that is markedly offset from that of chironomids (Fig. 2b), suggesting a significant difference in the fractionation of oxygen isotopes among the various chitin-forming animals. This difference, and the possibility of interspecific variation among chironomid species, both warrant further investigation.

\section{Conclusions}

The results from this investigation indicate that temperature exerts a modest but measurable influence on $\alpha^{18} \mathrm{O}_{\text {chironomid- } \mathrm{H}_{2} \mathrm{O}}$ that is summarized in Eq. (2) and which should be taken into account in future studies using $\delta^{18} \mathrm{O}_{\text {chironomid }}$ as a proxy for lake water $\delta^{18} \mathrm{O}$. As the present data set is small, further laboratory- and field-based calibration studies are needed to augment our findings and improve the estimates of coefficients in our equation. The variation of $\delta^{18} \mathrm{O}_{\text {chironomid }}$ with temperature, although small, may have significance when $\delta^{18} \mathrm{O}_{\text {chironomid }}$ values are used in palaeoenvironmental investigations. This is especially so in studies that combine $\delta^{18} \mathrm{O}_{\text {chironomid }}$ and $\delta^{18} \mathrm{O}_{\mathrm{CaCO}_{3}}$ data from lakes in order to reconstruct water temperature (Verbruggen et al. 2010b). 
Acknowledgements Funding was provided by a research studentship (NE/H008160/1) from the UK Natural Environment Research Council to AL. This work was undertaken by AL as part of his $\mathrm{PhD}$ at University College London. Co-authors are listed alphabetically. We thank Jim Ball for undertaking the water analyses and Gabriel Bowen for providing some of the data plotted in Fig. 2. Maarten van Hardenbroek, Tom Whitmore and two anonymous reviewers provided constructive comments, which helped to improve the paper.

Open Access This article is licensed under a Creative Commons Attribution 4.0 International License, which permits use, sharing, adaptation, distribution and reproduction in any medium or format, as long as you give appropriate credit to the original author(s) and the source, provide a link to the Creative Commons licence, and indicate if changes were made. The images or other third party material in this article are included in the article's Creative Commons licence, unless indicated otherwise in a credit line to the material. If material is not included in the article's Creative Commons licence and your intended use is not permitted by statutory regulation or exceeds the permitted use, you will need to obtain permission directly from the copyright holder. To view a copy of this licence, visit http://creativecommons.org/licenses/by/4.0/.

\section{References}

Aucour AM, Hillaire-Marcel C, Bonnefille, R (1993) A 30,000 year record of ${ }^{13} \mathrm{C}$ and ${ }^{18} \mathrm{O}$ changes in organic matter from an equatorial peatbog. In: Swart PK, Lohmann KC, McKenzie J, Savin S (eds) Climate change in continental isotopic records. American Geophysical Union Geophysical Monograph 78, 343-351

Beuning KRM, Kelts K, Ito E, Johnson TC (1997) Paleohydrology of Lake Victoria, East Africa, inferred from ${ }^{18} \mathrm{O} /{ }^{16} \mathrm{O}$ ratios in sediment cellulose. Geology 25:1083-1086

Brandriss ME, O’Neil JR, Edlund MB, Stoermer EF (1998) Oxygen isotope fractionation between diatomaceous silica and water. Geochim Cosmochim Acta 62:1119-1125

Chang JC, Shulmeister J, Gröcke DR, Woodward CA (2018) Toward more accurate temperature reconstructions based on oxygen isotopes of subfossil chironomid head-capsules in Australia. Limnol Oceanog 63:295-307

Hauer FR, Benke AC (1991) Rapid growth of snag-dwelling chironomids in a blackwater river: the influence of temperature and discharge. J North Am Bentholog Soc 10:154-164

Juillet-Leclerc A, Labeyrie L (1987) Temperature dependence of the oxygen isotopic fractionation between diatom silica and water. Earth Planet Sci Lett 84:69-74

Kim ST, O'Neil JR (1997) Equilibrium and nonequilibrium oxygen isotope effects in synthetic carbonates. Geochim Cosmochim Acta 61:3461-3475

Lasher GE, Axford Y, McFarlin JM, Kelly MA, Osterberg EC, Berkelhammer MB (2017) Holocene temperatures and isotopes of precipitation in Northwest Greenland recorded in lacustrine organic materials. Quat Sci Rev 170:45-55
Leng MJ, Barker P (2006) A review of the oxygen isotope composition of lacustrine diatom silica for palaeoclimate reconstruction. Earth-Sci Rev 75:5-27

Leng MJ, Marshall JD (2004) Palaeoclimate interpretation of stable isotope data from lake sediment archives. Quat Sci Rev 23:811-883

Lombino AG (2015) The systematics of oxygen isotopes in chironomids: a tool for reconstructing past climate. Unpubl PhD thesis, University College London, UK

Mayr C, Laprida C, Lucke A, Martín RS, Massaferro J, Ramón Mercau J, Wissel H (2015) Oxygen isotope ratios of chironomids, aquatic macrophytes and ostracods for lakewater isotopic reconstructions. Results of a calibration study in Patagonia. J Hydrol 529:600-607

Nielson KE, Bowen GJ (2010) Hydrogen and oxygen in brine shrimp chitin reflect environmental water and dietary isotopic composition. Geochim Cosmochim Acta 74:1812-1822

Qi H, Coplen TB, Wassenaar LI (2011) Improved online $\delta^{18} \mathrm{O}$ measurements of nitrogen- and sulfur-bearing organic materials and a proposed analytical protocol. Rapid Commun Mass Spectrom 25:2049-2058

Schilder J, Tellenbach C, Most M, Spaak P, van Hardenbroek M, Wooller MJ, Heiri O (2015) The stable isotopic composition of Daphnia ephippia reflects changes in $\delta^{13} \mathrm{C}$ and $\delta^{18} \mathrm{O}$ values of food and water. Biogeosciences 12:3819-3830

Schimmelmann A, DeNiro MJ (1986) Stable isotopic studies on chitin III. The ${ }^{18} \mathrm{O} /{ }^{16} \mathrm{O}$ and $\mathrm{D} / \mathrm{H}$ ratios in arthropod chitin. Geochim Cosmochim Acta 50:1485-1496

Schimmelmann A, DeNiro MJ, Poulicek M, Voss-Foucart MF, Goffinet G, Jeuniaux C (1986) Isotopic composition of chitin from arthropods recovered in archaeological contexts as palaeoenvironmental indicators. J Archaeological Sci 13:553-566

Soto DX, Wassenaar LI, Hobson KA (2013) Stable hydrogen and oxygen isotopes in aquatic food webs are tracers of diet and provenance. Functional Ecol 27:535-543

van Hardenbroek M, Gröcke DR, Sauer P, Elias SA (2012) North American transect of stable hydrogen and oxygen isotopes in water beetles from a museum collection. J Paleolimnol 48:461-470

van Hardenbroek M, Chakraborty A, Davies KL, Harding P, Heiri O, Henderson ACG, Holmes JA, Lasher GE, Leng MJ, Panizzo VN, Roberts L, Schilder J, Trueman CN, Wooller MJ (2018) The stable isotope composition of organic and inorganic fossils in lake sediment records: Current understanding, challenges, and future directions. Quat Sci Rev 196:154-176

Verbruggen F, Heiri O, Reichart GJ, Blaga C, Lotter AF (2011) Stable oxygen isotopes in chironomid and cladoceran remains as indicators for lake water $\delta^{18} \mathrm{O}$. Limnol Oceanog 56:2071-2079

Verbruggen F, Heiri O, Reichart GJ, de Leeuw JW, Nierop KGJ, Lotter AF (2010a) Effects of chemical pretreatments on $\delta^{18} \mathrm{O}$ measurements, chemical composition, and morphology of chironomid head capsules. J Paleolimnol 43:857-872

Verbruggen F, Heiri O, Reichart GJ, Lotter AF (2010b) Chironomid $\delta^{18} \mathrm{O}$ as a proxy for past lake water $\delta^{18} \mathrm{O}$ : a 
Lateglacial record from Rotsee (Switzerland). Quat Sci Rev 29:2271-2279

Wang YV, O'Brien DM, Jenson J, Francis D, Wooller MJ (2009) The influence of diet and water on the stable oxygen and hydrogen isotope composition of Chironomidae (Diptera) with paleoecological implications. Oecologia 160:225-233

Wooller MJ, Francis D, Fogel ML, Miller GH, Walker I, Wolfe AP (2004) Quantitative paleotemperature estimates from $\delta^{18} \mathrm{O}$ of chironomid head capsules preserved in arctic lake sediments. J Paleolimnol 31:267-274

Publisher's Note Springer Nature remains neutral with regard to jurisdictional claims in published maps and institutional affiliations. 